\title{
Ethiopian volcanic hazards: a changing research landscape
}

C. Vye-Brown ${ }^{1 *}$, R.S.J. Sparks ${ }^{2}$, E. Lewi ${ }^{3}$, G. Mewa ${ }^{3}$, A. Asrat ${ }^{4}$, S.C. Loughlin ${ }^{1}$, K. Mee ${ }^{5}$ and T.J. Wright $^{6}$

${ }^{1}$ British Geological Survey, The Lyell Centre, Research Avenue South, Edinburgh, EH14 4AP, UK

${ }^{2}$ School of Earth Sciences, University of Bristol, Wills Memorial Building, Queens Road, Bristol BS8 1RJ, UK

${ }^{3}$ Institute of Geophysics, Space Science and Astronomy, Addis Ababa University, Addis Ababa, Ethiopia

${ }^{4}$ School of Earth Sciences, Addis Ababa University, Addis Ababa, Ethiopia

${ }^{5}$ British Geological Survey, Environmental Science Centre, Nicker Hill, Keyworth, Nottingham, NG12 5GG, UK

${ }^{6}$ School of Earth and Environment, Maths/Earth and Environment Building, The University of Leeds, Leeds, LS2 9JT, UK

*Corresponding author (email: cvye@bgs.ac.uk)

Collaborative research projects have a significant role in filling the knowledge gaps that are obstacles to the rigorous assessment of volcanic hazards in some locations. Research is essential to generate the evidence on which raising awareness of volcanic hazards, monitoring and early warning systems, risk reduction activities and efforts to increase resilience can be built. We report the current state of volcanic hazards research and practice in Ethiopia and on the collaborative process used in the Afar Rift Consortium project to promote awareness of volcanic hazards. Effective dissemination of findings to stakeholders and the integration of results in existing practice needs: leadership by in-country researchers, effective long-term collaboration with other researchers (e.g. international groups) and operational scientists, in addition to integration with existing programmes related to disaster risk reduction initiatives.

There is an increasing need for the science-based characterisation of natural hazards to support risk assessment and disaster risk management (DRM) programmes (Alcántara-Ayala et al. 2015; United Nations Office for Disaster Risk Reduction 2015a). This need exists at local, national and global levels and requires the engagement of individuals, communities, governments and international agencies (United Nations Office for Disaster Risk Reduction 2015b). Ensuring that externally funded scientific research plays an effective and timely role in DRM at all levels requires collaboration with in-country scientists (Paton et al. 2008; Mercer et al. 2010). It also requires the generation and application of a variety of tools and products that meet the needs and expectations of users. 
Volcanic eruptions are one of the few natural phenomena that can have consequences at a global level. Volcanic activity can result in loss of life ( 280,000 since AD 1600, Auker et al. 2013), as well as environmental, social and economic losses (e.g. Gencer 2013). However, it was not until the moderately sized eruption of the Eyjafjallajökull volcano in Iceland in 2010 caused serious disruption to air traffic across the northern hemisphere (Porkelsson 2012) that the potential global impact from erupting volcanoes became widely acknowledged. The Eyjafjallajökull 2010 eruption accumulated about US\$ 5 billion of global economic losses and adversely affected long-haul aviation, trade and travel around the world (Ragona et al. 2011).

Volcanic hazards have subsequently been included in global hazards and risk initiatives, such as the Global Assessment Report (GAR; United Nations Office for Disaster Risk Reduction 2015b). The 2015 GAR (GAR15) aimed to 'promote the integration of disaster risk management into development by raising the awareness that managing risks cost less than managing disasters' (United Nations Office for Disaster Risk Reduction 2016). As a global level report, GAR15 had a coarse resolution to highlight comparable risks. Assessments at a finer resolution (national and local scales) are the responsibility of the respective nations. GAR15 summarised progress towards the goals of the Hyogo Framework for Action 2005-15, which aimed to reduce disaster losses substantially by 2015 by building the resilience of nations and communities to disasters (United Nations Office for Disaster Risk Reduction 2005). The Sendai Framework for Disaster Risk Reduction (SFDRR) 2015-30 is the successor to the Hyogo Framework for Action and has four priorities for action, to: 1) understand disaster risk; 2) strengthen disaster risk governance to manage disaster risk; 3 ) invest in disaster risk reduction (DRR) for resilience; and 4) enhance disaster preparedness for effective response and to 'build back better' in recovery, rehabilitation and reconstruction (United Nations Office for Disaster Risk Reduction 2015a). The SFDRR encourages national leadership and responsibility for in-country DRR programmes. The SFDRR is a driver for change and national progress to which individual nations respond. As a result, there is now a policy-driven need for key information on hazards and assessments of risk at national levels to support both short-term reactive policies, such as disaster relief, as well as long-term proactive strategies, such as integration of research into decision-making and preparedness.

Volcanoes are notable in having many hazards associated with, and produced by, any single volcano that vary in character both in space and time. These characteristics may subsequently and sequentially compound the impact of any unrest and/or eruption(s). Therefore the threats, risks and potential impacts associated with volcanoes are varied and complex. There is a need for further strategic research to address key knowledge gaps and to increase our understanding of volcanic histories, volcanic hazards and potential impacts (Loughlin et al. 2015; United Nations Office for Disaster Risk Reduction 2015b; Aspinall et al. 2011). However, research alone has limited impact unless the outcomes can be applied locally by in-country researchers to deliver accessible data to decision-makers that directly address user needs (Hicks et al. 2014; Brown et al. 2015c). Establishing relevant and 
effective communication between scientists and decision makers is needed with consideration of existing programmes, policies and methodologies to assist in effective longterm planning, for disaster management and also to increase resilience (Weichselgartner and Kasperson 2010; Gaillard and Mercer 2013).

We present here a review of current engagement and UK-funded research on volcanic hazards in Ethiopia. The Afar Rift Consortium (ARC) has conducted research that has contributed key new data to address the gaps in our knowledge and enabled the consideration of future actions for the mitigation of hazards and risks. We summarise the status of existing approaches to volcanic hazards, risk management and current research in Ethiopia and discuss the outcomes in terms of how the international research community could effectively collaborate with in-country scientists to support existing planning and DRR initiatives.

\section{Volcanic hazards and risk assessments}

The characterisation and assessment of volcanic hazards and risk is required across countries, regions, and globally to support the economic, social and political aspects of planning, mitigation and DRR initiatives.

At an international scale, methods that enable a relative assessment of national hazards and risk are valuable for assessing progress towards international SFDRR goals. In volcanology, an index-based methodology was introduced in a study for the World Bank (Aspinall et al. 2011) which was then developed further to deliver the first global assessment of volcanic hazards and threats for GAR15 (Loughlin et al. 2015). The revised methods consider hazards (Auker et al. 2015) and exposure (Brown et al. 2015b). However, although population exposure can be easily assessed for any area of the world using this approach, the volcanic hazard index is difficult to establish unless there are sufficient data. The results of the GAR15 assessment of volcanic hazards and risks at a national level can be compared globally to provide a relative index of volcanic risks for integration into national programmes in addition to regional cooperation for all countries (Loughlin et al. 2015).

Traditionally, both quantitative and qualitative assessments of volcanic hazards (and sometimes risk) usually focus on the local and volcano scales (Brown et al. 2015c). Largely as a result of data limitations, quantitative assessments of volcanic hazards and risk are still only available in a few localities worldwide (e.g. Marzocchi et al. 2004; Haynes et al. 2007). One method of assessing and communicating hazards around individual volcanoes has traditionally been hazard mapping. There are many different forms of volcanic hazard maps and the most commonly used geology-based hazard maps are based on knowledge of prior eruptions and their distributed products (Calder et al. 2015). However, this does not represent the range of future scenarios; probabilistic computational modelling is required to fill the gaps in knowledge. There are currently no hazard maps for Ethiopia's volcanoes. 


\section{Volcanic hazards and risk assessments in Ethiopia}

Fifty-nine Holocene volcanoes are currently known in Ethiopia, of which just over half lie in the Afar Depression (Figure 1; Abebe et al. 2007; Siebert et al. 2010). They form two distinct lines of volcanoes which can be seen within the East African Rift. The first line is the Main Ethiopian Rift, a NE-trending line that bisects the middle of the country. The second line is oriented NNW, nearer the border with Eritrea, and consists of a series of smaller en-echelon lines of volcanoes in the area of the Afar Depression. As in other countries in the East African Rift, a significant number of these volcanoes are mafic with basaltic volcanic fields (cinder cones and fissures), shields and monogenetic cones with a predominantly effusive eruption style (Abebe et al. 2007); there is less evidence of explosive volcanism (Brown et al. 2015a). However, seven of Ethiopia's volcanoes are currently known to have produced felsic pyroclastic flow deposits, including some large volume ignimbrites (Brown et al. 2015a). The limited records of explosive volcanism in Ethiopia, whether due to poor preservation of the record or an absence of eruptions of this nature, should not be used to indicate a low probability of such an eruption in the future (Lenhardt and Oppenheimer 2014).

A preliminary assessment in GAR15 based on indices of hazard and population exposure for Ethiopia was problematic as a result of insufficient data for many of the known volcanic systems (Brown et al. 2015c). The data to inform this assessment were generally poor consequently there were large uncertainties about the scale and likely impact of past and future volcanism. Although none of the 59 volcanoes in Ethiopia were classified at the highest hazard level, large uncertainties in the data reflect poor baseline geological and historic knowledge.

The population exposure to volcanic hazards in Ethiopia is high; there are c. 1.5 million people (1.6\% of the population) living within $10 \mathrm{~km}$ of a Holocene volcano, over 11 million (12.3\%) within $30 \mathrm{~km}$, and over 42 million (46.5\%) within $100 \mathrm{~km}$ (Brown et al. 2015a). Based on the calculated population exposure index, the following systems have high exposure in Ethiopia: the Bishoftu Volcanic Field, Sodore, the Butajiri Silti Field, Corbetti Caldera, the Bilate River Field and Hobicha Caldera (Fig. 1). However, volcanoes that have been active since with 1900 with a lower population exposure could pose greater risks as a result of a higher hazard ranking, including: Alutu, Fentale, Kone and Tullu Moje. The population data used for GAR15 were from the Oak Ridge National Laboratory LandScan 2011 dataset (Bright et al. 2012). Comparison of population datasets reveals a decrease in the level of exposure at $10 \mathrm{~km}$ from some volcanoes in the Main Ethiopian Rift whilst there is a general increase in the level of exposure above levels of average population growth (Table 1; Fig. 2). There are known to be discrepancies with the census data in Ethiopia, probably as a result of rapid population growth and development. Based on data from 2000 to 2011 the average population growth rate is estimated to be $2.7 \%$ (Central Statistical Agency 2013). 
This research provides a useful basis for planning within Ethiopia, supporting decisionmaking at local and regional levels, despite the high uncertainties. The volcanic record is particularly poor in Ethiopia and there is no explicit eruptive history for each of the 59 volcanoes (Loughlin et al., 2015). As such, under-reporting may underestimate the hazard and attendant risks posed both in the past and at present. Raising the baseline knowledge of volcanism and volcanic hazards is therefore imperative.

\section{Existing approaches to volcanic hazard and risk management}

There is no mandated or dedicated institution for volcano monitoring in Ethiopia, but collectively the Institute of Geophysics, Space Science and Astronomy and School of Earth Sciences in Addis Ababa University provide scientific advice to the National Disaster Risk Management Commission (NDRMC; formerly the Disaster Risk Management and Food Security Sector), the Civil Aviation Authority and the Ethiopian Pilots Association during an eruption (Fig. 3). The Geological Survey of Ethiopia is the national institution producing geoscience data, advice and services that contribute to the sustainable development of the agricultural, industrial, infrastructure and other sectors of the Ethiopian economy to improve living standards. The NDRMC, under the Prime Minister's Office, is the government department responsible for civil protection and managing the response to mitigate disasters as a result of natural hazards. The NDRMC includes the Early Warning \& Response Directorate and is responsible at a national level for all aspects of prevention, preparation, response and recovery. In 2013, the NDRMC marked a shift from reactive crises management to proactive DRM and launched the Wereda Disaster Risk Profiling Programme that adopted the Hyogo Framework for Action to strengthen community resilience. At the time of writing, there is no formal protocol or communication method between these institutions for scientific advice, whether reactive to unrest or a crisis, or to facilitate long-term planning.

\section{Historical volcanism and magmatism in the Afar Rift}

The high uncertainty and lack of geological knowledge of Ethiopia's volcanoes make research projects such as the ARC very important in providing data that can contribute to global databases. The ARC was funded by the UK Natural Environment Research Council to conduct research into the active magmatism, tectonism and volcanism of the Afar Rift in northeastern Ethiopia from 2006 to 2012 (e.g. Wright et al. 2012, and references cited therein).

The margins of the Afar Depression are marked by the Ethiopian Plateau to the west, Somali Plateau to the SE and Danakil Highlands to the NE (Fig. 1). Since the emplacement of the Ethiopian Trap Basalts from c. 31-29 Ma, the Arabian plate has been moving away from the Nubian plate to form the Red Sea (Ebinger et al. 1993; Hofmann et al. 1997; Wolfenden et al. 2005). The inland continuation of the Red Sea extension is displayed in en-echelon discrete magmatic rift segments c. $60 \mathrm{~km}$-long, which are the foci for volcanic and tectonic 
activity: Erta'Ale, Tat'Ale, Alayta and Dabbahu-Manda Hararo (Hayward \& Ebinger 1996; Ebinger \& Casey 2001; Acocella et al. 2008). The Dabbahu-Manda Hararo magmatic segment is the southernmost segment to display the NW - SE orientation of the Red Sea Rift in Afar and therefore marks the propagating tip of the Red Sea Rift (Acocella et al. 2008).

A new rifting episode started in the Dabbahu-Manda Hararo magmatic segment on the 23 September 2005. The dramatic initiation of this episode was marked by a large dyke emplacement event and was accompanied by a small rhyolitic explosive eruption from a fissure at the northern tip of the dyke (Wright et al. 2006; Ayele et al. 2009). This single rifting event opened a series of fissures and reactivated faults with vertical surface displacements of up to 1.5 metres along a $60 \mathrm{~km}$ long portion of the magmatic segment close to the axis. The $2.5 \mathrm{~km}^{3}$ dyke originated from a magmatic source located in the centre of the rift zone (Hamling et al. 2009) and the emplacement was detected by seismicity (c. 163 low magnitude earthquakes) and surface deformation using InSAR (Wright et al. 2006).

Since 2005 , this magmatic segment has been the subject of intense investigation by an international team of researchers using seismology, InSAR, global positioning system data, petrology, magnetotellurics, gravity and geological mapping to characterise the rifting cycle and crustal structure beneath Afar. The thickness of the crust beneath Afar has been reported to vary from c. $16 \mathrm{~km}$ in the north to $c .45 \mathrm{~km}$ beneath the Ethiopian Plateau and to contain significant amounts of melt (Hammond et al. 2011). Since monitoring began, 13 basaltic dykes have been emplaced, accounting for up to $8 \mathrm{~m}$ of extension across the magmatic segment (Hamling et al. 2009, 2010), and three small volume basaltic eruptions have occurred (Ferguson et al. 2010). The eruptions originated from the southern and central parts of the axial graben in 2007, 2009 and 2010. The first two eruptions were larger in volume (4.4-8.8 $\times 10^{6}$ and $13.5-18 \times 10^{6} \mathrm{~m}^{3}$, respectively) and the basaltic lava flows for each eruption were extruded from the same fissure vent system (Ferguson et al. 2010). The fissure-fed lavas produced during these eruptions were emplaced as rubbly pāhoehoe flows up to 2 metres thick.

In addition to the eruptions of the southern part of the Manda Hararo Rift, there have been 11 additional historic eruptions within the Afar Depression (Pagli et al. 2012; Pyle 2012; Brown et al., 2015a). With a few exceptions, the most recent volcanism in the Afar Depression has been effusive and basaltic. These observations have been analysed to look for patterns of behaviour which may enable a probabilistic approach to assess the likelihood of future eruptions and the occurrence of hazards (Yirgu et al. 2014). However, the current dataset is very small. Despite the seemingly remote location of these eruptions relative to the population centres, the impacts have been significant. For example, the Nabro eruption in 2011 produced an ash plume and released an estimated $1.3 \mathrm{Tg}$ of sulphur dioxide (Bourassa et al. 2012). Unofficial reports suggest that the eruption caused 32 fatalities, displaced $>5000$ people, disrupted regional aviation, and that the contamination of food and water resources by ash resulted in up to 48000 people requiring aid (Yirgu et al. 2014). 


\section{Current research in Ethiopia}

Ethiopia is ranked eleventh of 233 countries in terms of vulnerability to physical climate impacts and ninth in terms of overall vulnerability (Centre for Global Development 2010). As a result, there have been advances in the levels of knowledge and expertise in DRM (Few et al. 2014). Ethiopia has advanced early warning systems (Tadele \& Manyena 2009), particularly related to drought and food security (Ludi et al. 2013). There is also a large body of research on DRR, climate adaptation and vulnerability in Ethiopia (Ludi et al. 2011; Silva Vilanueva 2011). Although systems are in place for the expansion of this knowledge to other geophysical hazards, this body of research has yet to include volcanic hazards.

At the time of writing there are no ground-based systems dedicated to the long-term monitoring of volcanoes in Ethiopia (Brown et al. 2015a). However, there is a national seismic array consisting of 12 seismometers operated by the Institute of Geophysics, Space Science and Astronomy, which is in the process of being partially upgraded to provide realtime data. Despite the lack of ground-based monitoring, satellite observations have enabled identification of several volcanoes in Ethiopia that have experienced deformation in the last decade (Biggs et al. 2011).

Much of the recent research in natural hazards in Ethiopia has been possible due to the strength of the collaboration between Ethiopian researchers and international colleagues arising from decades of previous working relationships. International funding has supported research collaborations and engagement with stakeholders in Ethiopia (Fig. 4). One engagement activity was a workshop attended by 32 people in Addis Ababa in January 2012, where geohazards in Ethiopia were discussed with the aim of raising the awareness of volcanic hazards (Vye-Brown 2014). The following narrative is based on the focussed discussions held at this workshop to identify critical needs and areas for work. A much larger discussion between academic collaborators, practitioners and decision-makers needs to be had in the future to address key needs and knowledge gaps through collaborative partnerships to support implementation of the SFDRR framework in Ethiopia.

\section{Needs for future volcanic hazard and risk research in Ethiopia}

Hydrometeorological hazards and landslides are the most common geophysical hazards in Ethiopia and have the highest impact. Therefore decision- and policy-makers have the greatest awareness and plans for DRM in these areas. Although there are dedicated institutions researching geological hazards, there is no dedicated institution for volcanic hazards in Ethiopia. In addition, volcanic hazards rank as a comparatively low priority compared with hydro-meteorological hazards, landslides, drought and famine. Volcanic hazards account for $<1 \%$ of the hazards occurring on the African continent but this low occurrence rate does not mean that the current risk is low or may not pose a significant threat in the future (OFDA-CRED 2012). Many mitigation measures and planning and disaster management methods that are applied to other natural hazards could be adapted 
for responses to volcanic hazards and could assist with planning for volcanic eruptions (e.g. Barclay et al. 2008).

The requirements for geohazard monitoring, assessment and mitigation in Ethiopia are numerous. The multi-disciplinary ARC research and the increased monitoring capacity afforded by instrumentation deployed to monitor activity from 2006 to 2012 provided invaluable insights into magmatism and volcanism in the Afar Rift. However, such timelimited investments provided by research projects do not provide the sustainability needed for DRM. Capacity building is needed in Ethiopia to support the acquisition of instrumentation, software for data processing and training. Furthermore, access to satellite data, mapping techniques and resources with which to assess vulnerability and risk are needed to develop hazard and risk products (e.g. maps and reports). Researchers in Ethiopia do not conduct impact assessments for volcanic hazards. A key need in Ethiopia is the identification of resources, data and institutions that could be used to assess geophysical hazards as well as collaboration with international colleagues.

Hazard information should be disseminated to all stakeholders at local and national levels in Ethiopia. Integrated co-ordination between in-country departments is currently lacking but there is an established department (NDRMC) to whom real-time data should be disseminated in the event of volcanic unrest and eruptions. It was suggested that the development of a group of scientists with complementary expertise to provide advice on natural hazards would help to raise the awareness of this area with NDRMC, as well as other government departments.

Vulnerability to geophysical hazards is not an area of widespread knowledge or research in Ethiopia. Collaborations with research partners working on hydrometeorological hazards would support future work on vulnerability for other geophysical hazards.

International collaboration and exchanges are important aspects of capacity building in Ethiopia. Aspects of capacity building can be incorporated into future research projects to further expand on the resources and capacity in Ethiopia. Funding for capacity building may be sought from development initiatives.

Funding to support all of these areas of work, both the additional research and the application to DRR, could be sought internationally and in Ethiopia.

\section{Priorities for action}

The Addis Ababa stakeholder workshop held in January 2012 (Vye-Brown 2014) identified the following as priorities for action.

Local leadership and in-country co-ordination and engagement - Co-ordination by a national scientific team in-country is essential to deliver, receive and share information, to bring together expertise from across departments, to enable decision-making and to form a 
long-term mandate that includes work in non-emergency situations. This team could form an Ethiopian natural hazards scientific advisory group.

Hazard and risk communication - There is an outstanding need to identify further national and international organisations and personnel that are active in this field and to establish communication links. Engagement between scientists and stakeholders in DRR and DRM is essential for effective communication and the provision of timely and accurate scientific advice, whether for short-term response to events or long-term planning. User needs assessments are required to identify appropriate communication pathways, institutional responsibilities and requirements for data for both scenarios. In addition, communication pathways need to be established between government, regional and local community levels.

Capacity building for strategic monitoring - Although campaign networks of seismometers and GPS instruments were deployed for the duration of the ARC project, this network was not maintained for the purpose of long-term monitoring of volcanic activity in Ethiopia. The local seismic network is primarily positioned for observing tectonic earthquakes. The network consists of 12 instruments distributed around Ethiopia. Therefore the identification and observation of volcanic eruptions in remote areas of Ethiopia is currently almost entirely reliant on satellite observations and the dissemination of these observations by international researchers to Ethiopian colleagues. The Toulouse Volcanic Ash Advisory Centre has responsibility for projecting the dispersion of volcanic ash in the airspace across Africa. However, there is no other formal method (e.g. utilising available satellite images) that is directly accessible in Ethiopia as a resource for in-country scientists and decisionmakers to monitor eruptions or unrest on the ground. Facilities development and training are essential in this area.

Funding - The perception of volcanic risks as a low priority in Ethiopia is due in part to the fact that there have been no medium to large-scale volcanic eruptions in recent history and the documented losses from eruptions have been relatively small (Brown et al. 2015a). As a result, there has been almost no investment in volcanic hazards and risk to date and awareness among decision-makers is low. Education is required to address this, led by Ethiopian scientists, operating as a single voice. Existing research in the fields of drought and famine in Ethiopia highlights the high costs of a late humanitarian response compared with resilience building activities (US\$3.3 billion more; Venton 2012). Furthermore, it is understood that resilience-building activities are significant for the economic development of Ethiopia. There are several levels at which DRR is conducted and therefore funding could be sought: international, national and local. Prioritisation is needed, using existing hazard and risk assessments, to identify where the most difference can be made with limited resources.

\section{Outcomes}


There are complexities in both short-term volcanic hazard assessments, beyond simply the availability of monitoring equipment, and in long-term hazard assessments. For example, one of the key SFDRR priorities is identifying the risk, but how do we accomplish this for volcanic areas in close to real-time without identifying the variations in hazards in both time and space through monitoring? Monitoring needs to be maintained in the long term to establish background levels and normal variations so that the thresholds for changing behaviour can be identified. A key challenge is to establish methods for reducing volcanic risk in a cost-effective way in countries such as Ethiopia.

Volcanic hazard and risk research in Ethiopia has secured follow-on funding from 2014 to 2019 in the NERC-funded RiftVolc project. This funding will enable the next steps in volcanic hazard and risk research in Ethiopia. In particular, the potential future threat from volcanic activity through probabilistic volcanic hazard assessments and modelling at some volcanoes with high population exposures in the Main Ethiopian Rift will be investigated (Aspinall et al. 2011; Brown et al. 2015a) in addition to a regional assessment of risk under conditions of uncertainty. This research was developed in collaboration with Ethiopian scientists and decision-makers to maximise opportunities to integrate the results into long-term planning and DRM programmes within Ethiopia.

\section{Conclusions}

Although there are well-established DRM practices within Ethiopia, an established link has not yet been made between practitioners, policy- and decision-makers, and research scientists for low frequency events such as geophysical hazards. Geophysical hazards in Ethiopia are not as frequent as hydrometeorological hazards and hence they have a relatively low priority. The integration of these hazards within existing DRM and DRR programmes for other high-frequency hazards (e.g. droughts) is essential for facilitating the incorporation of scientific research into DRM for volcanoes.

There are many challenges to the collaborative process, including: engagement with the relevant stakeholders for DRR and DRM for low-frequency hazards; communication and transfer of knowledge; building trust; the distribution and share of workloads between international and in-country collaborators; and delivering research whilst simultaneously addressing both local and global DRR agendas. Although the needs and priorities presented are specifically for Ethiopia, these may also be relevant for other nations seeking to address the aims of the SFDRR.

\section{Acknowledgements}

This work has been supported by National Environmental Research Council Afar Rift Consortium grant NE/F007604/1 and the British Geological Survey. We sincerely thank the University of Addis Ababa and the Geological Survey of Ethiopia for generous support of workshop and fieldwork logistics, and the Afar Regional Government for invaluable 
assistance. We thank John Rees for fruitful discussions. CVB publishes with the permission of the Executive Director of the British Geological Survey (Natural Environment Research Council). We acknowledge constructive comments from two anonymous reviewers.

\section{References}

Abebe, B., Acocella, V., Korme, T., \& Ayalew, D. 2007. Quaternary faulting and volcanism in the Main Ethiopian Rift. Journal of African Earth Sciences, 48(2), 115-124

Acocella, V., Abebe, B., Korme, T., \& Barberi, F. 2008. Structure of Tendaho graben and Manda Hararo rift: Implications for the evolution of the southern Red Sea propagator in Central Afar: Tectonics, v. 27, TC4016, doi:10.1029/2007TC002236

Alcántara-Ayala, I., Altan, O., Baker D., Briceño, S., Cutter, S., Gupta, H., Holloway, A., IsmailZadeh, A., Jiménez Díaz, V., Johnston, D., McBean, G., Ogawa, Y., Paton, D., Porio, E., Silbereisen, R., Takeuchi, K., Valsecchi, G., Vogel, C., Wu, G. \& Zhai, P. 2015. Disaster Risks Research and Assessment to Promote Risk Reduction and Management. ICSU-ISSC, http://www.icsu.org/science-for-policy/disasterrisk/documents/DRRsynthesisPaper_2015.pdf

Aspinall, W., Auker, M., Hincks, T., Mahony, S., Nadim, F., Pooley, J., Sparks, R. \& Syre, E. 2011. Volcano hazard and exposure in GFDRR priority countries and risk mitigation measures - GFDRR Volcano Risk Study. Bristol: Bristol University Cabot Institute and NGI Norway for the World Bank: NGI Report, 20100806, 3.

Ayele, A., Keir, D., Ebinger, C., Wright, T.J., Stuart, G.W., Buck, W.R., Jacques, E., Ogubazghi, G., and Sholan, J. 2009. September 2005 mega-dike emplacement in the Manda-Harraro nascent oceanic rift (Afar depression) Geophysical Research Letters, vol. 36, L20306

Auker, M.R., Sparks, R.S.J., Siebert, L., Crosweller, H.S., \& Ewert J. 2013. A statistical analysis of the global historical volcanic fatalities record. Journal of Applied Volcanology, 2, http://doi.org/10.1186/2191-5040-2-2

Auker, M.R., Sparks, R.S.J., Jenkins, S.F., Aspinall, W., Brown, S.K., Deligne, N.I., Jolly, G., Loughlin, S.C., Marzocchi, W., Newhall, C.G. \& Palma, J.L. 2015. Development of a new global Volcanic Hazard Index (VHI). In Loughlin, S.C., Sparks, R.S.J., Brown, S.K., Jenkins, S.F., Vye-Brown, C. (eds.) Global Volcanic Hazards and Risk, Cambridge University Press, 349-358

Barclay, J., Haynes, K., Mitchell, T., Solana, C., Teeuw, R., Darnell, A., Crosweller, H., Cole, P., Pyle, D., Lowe, C., Fearnley, C., \& Kelman, I. 2008. Framing volcanic risk communication within disaster risk reduction: Finding ways for the social and physical sciences to work together. Geological Society, London. Special Publication 305, 163-177 
Biggs, J., Bastow, I. D., Keir, D. \& Lewi, E. 2011. Pulses of deformation reveal frequently recurring shallow magmatic activity beneath the Main Ethiopian Rift. Geochemistry, Geophysics, Geosystems, 12 (9), Q0AB10

Bourassa, A. E., Robock, A., Randel, W. J., Deshler, T., Rieger, L. A., Lloyd, N. D., Llewellyn, T. \& Degenstein, D. A. 2012. Large volcanic aerosol load in the stratosphere linked to Asian monsoon transport. Science, 337 (6090), 78-81

Bright, E. A., Coleman, P. R., Rose, A. N. \& Urban, M. L. 2012. LandScan 2011. Oak Ridge National Laboratory, TN, USA. Available: web.ornl.gov/sci/landscan

Brown, S.K., Sparks, R.S.J., Mee, K., Vye-Brown, C., Ilyinskaya, E., Jenkins, S.F. \& Loughlin, S.C. 2015a. Country and regional profiles of volcanic hazard and risk. Appendix B [online]. In: Loughlin, S.C., Sparks, R.S.J., Brown, S.K., Jenkins, S.F., Vye-Brown, C. (eds.) Global Volcanic Hazards and Risk, Cambridge University Press, Cambridge

Brown, S.K., Auker, M.R. \& Sparks, R.S.J. 2015b. Populations around Holocene volcanoes and development of a Population Exposure Index. In: Loughlin, S.C., Sparks, R.S.J., Brown, S.K., Jenkins, S.F., Vye-Brown, C. (eds.) Global Volcanic Hazards and Risk, Cambridge University Press, Cambridge, 223-232

Brown S.K., Loughlin, S.C., Sparks, R.S.J., Vye-Brown, C., Barclay, J., Calder, E. Cottrell, E. Jolly, G., Komorowski, J-C. Mandeville, C. Newhall, C., Palma, J., S. Potter, S. \& Valentine, G. 2015. Global volcanic hazard and risk. In: Loughlin S.C., Sparks, R.S.J., Brown, S.K., Jenkins, S, Vye-Brown, C. (Eds) Global volcanic hazards and risk, Part 2. Cambridge University Press, Cambridge, 76-167

Calder, E. S., Wagner, K., \& Ogburn, S. E. 2015. Volcanic hazard maps. In: Loughlin, S.C., Sparks, R.S.J., Brown, S.K., Jenkins, S.F., Vye-Brown, C. (eds.) Global Volcanic Hazards and Risk, Cambridge University Press, Cambridge, 335-342

Central Statistical Agency, 2013. Statistical Abstract, the Federal Democratic Republic of Ethiopia, Central Statistical Agency, Addis Ababa

Centre for Global Development 2010 Map and vulnerability ranking.

http://www.cgdev.org/section/topics/climate_change/mapping_the_impacts_of_climate_c hange [last accessed August 2015].

Ebinger, C. \& Casey, M. 2001. Continental breakup in magmatic provinces: An Ethiopian example. Geology 29, 527-530

Ebinger, C. J., Yemane, T., Woldegabriel, G., Aronson, J. L., \& Walter, R. C. 1993. Late Eocene-Recent volcanism and faulting in the southern main Ethiopian rift. Journal of the Geological Society, 150 (1), 99-108, http://doi.org/10.1144/gsjgs.150.1.0099 
ESRI Online 2014. Global GIS datasets including: World Shaded Relief, World Countries, World Cities, World Roads and World Airports. All available within ArcGIS version 10.1 http://www.esri.com/software/arcgis/arcgisonline/maps/maps-and-map-layers

Ferguson, D.J., Barnie, T.D., Pyle, D.M., Oppenheimer, C., Yirgu, G., Lewi, E., Kidane, T., Carn, S. \& Hamling, I.J. 2010. Recent rift-related volcanism in Afar, Ethiopia. Earth and Planetary Science Letters, doi:10.1016/j.epsl.2010.02.010

Few, R., Scott, Z., Tarazona, M., Bultosa, G., Berhanu, T. \& Tincani, L. 2014. Strategic Research into National and Local Capacity Building for DRM: Ethiopia Pilot Report. Oxford Policy Management.

http://www.preventionweb.net/files/39423_39416ethiopiapilotfieldworkreportif.pdf [last accessed September 2015]

Gaillard, J.C. \& Mercer, J., 2013. From knowledge to action: Bridging gaps in disaster risk reduction. Progress in Human Geography, 37, 93-114.

Gencer, E.A. 2013. Natural disasters, urban vulnerability, and risk management: a theoretical overview. In: Gencer, E.A. (ed.), The Interplay between Urban Development, Vulnerability, and Risk Management, Springer, New York, pp. 7-43

Hamling, I.J., Ayele, A., Bennati, L., Calais, E., Ebinger, E.J., Keir, D., Lewi, E., Wright, T., Yirgu, G., 2009. Geodetic observations of the ongoing Dabbahu rifting episode: new dyke intrusions in 2006 and 2007. Geophys. J. Int. 178, 989-1003

Hamling, I., Wright, T., Calais, E., Bennati, L. \& Lewi, E. 2010. Stress transfer between thirteen successive dyke intrusions in Ethiopia. Nature Geoscience Letters 3, 713-717 doi.10.1038/NGEO967

Hammond, J.O.S., Kendall, J.M., Stuart, G.W., Keir, D., Ebinger, C., Ayele, A. \& Belachew, M., 2011. The nature of the crust beneath the Afar triple junction: Evidence from receiver functions. Geochemistry, Geophysics, Geosystems, 12(12).

Haynes, K., Barclay, J., \& Pidgeon, N. 2007. Volcanic hazard communication using maps: an evaluation of their effectiveness. Bulletin of Volcanology, 70(2), 123-138

Hayward, N. J., \& Ebinger, C. J. 1996. Variations in the along-axis segmentation of the Afar Rift system. Tectonics, 15(2), 244-257.

Hicks, A., Barclay, J., Simmons, P., \& Loughlin, S. 2014. An interdisciplinary approach to volcanic risk reduction under conditions of uncertainty: a case study of Tristan da Cunha, Natural Hazards and Earth System Sciences 14, 1871-1887

Hofmann, C. 1997. Timing of the Ethiopian flood basalt event and implications for plume birth and global change. Nature 389, 838-841 
LandScan 2014. World population GIS dataset from LandScan.

http://web.ornl.gov/sci/landscan/

Lenhardt, N., \& Oppenheimer, C. 2014. Volcanism in Africa: geological perspectives, hazards, and societal implications. Extreme Natural Hazards, Disaster Risks and Societal Implications, 1, 169

Loughlin, S.C., Vye-Brown, C., Sparks, R.S.J., Brown, S.K., Barclay, J., Calder, E., Cottrell, E., Jolly, G., Komorowski, J-C., Mandeville, C., Newhall, C., Palma, J., Potter, S., Valentine, G. 2015. An introduction to global volcanic hazard and risk. In: S.C. Loughlin, R.S.J. Sparks, S.K. Brown, S.F. Jenkins \& C. Vye-Brown (eds) Global Volcanic Hazards and Risk, Cambridge University Press, Cambridge, 1-75

Ludi, E., Tesfaye, K. \& Levine, S. 2011. Preparing for the Future. Understanding the Influence of Development Interventions on Adaptive Capacity at Local Level in Ethiopia. Africa Climate Change and Resilience Alliance (ACCRA) Ethiopia Synthesis Report, 7, 1-64.

Ludi, E., Terefe, B., Calow, R. \& Birhane, G. 2013. Ethiopia's water resources, policies, and institutions. In: Calow, R., Ludi, E. \& Tucker, J. (eds) Achieving Water Security: Lessons from Research in Water Supply, Sanitation and Hygiene in Ethiopia. Practical Action Publishing, Rugby, http://doi.org/10.3362/9781780447636.002

Marzocchi, W., Sandri, L., Gasparini, P., Newhall, C., \& Boschi, E. 2004. Quantifying probabilities of volcanic events: the example of volcanic hazard at Mount Vesuvius. Journal of Geophysical Research: Solid Earth 109, B11201, http://doi.org/10.1029/2004JB003155

Mercer, J., Kelman, I., Taranis, L. \& Suchet-Pearson, S., 2010. Framework for integrating indigenous and scientific knowledge for disaster risk reduction. Disasters, 34, 214-239.

NGIA 2010. World Ports GIS dataset by the National Geospatial Intelligence Agency, Version 2010

http://msi.nga.mil/NGAPortal/MSI.portal?_nfpb=true\&_pageLabel=msi_portal_page_62\&p ubCode $=0015$

OFDA-CRED 2012. The OFDA-CRED International Disaster Database 2002. Centre for Research on the Epidemiology of Disasters (CRED). http://www.emdat.be/disaster-profiles

Pagli, C., Wright, T.J., Ebinger, C.J., Yun, S.H., Cann, J.R., Barnie, T. \& Ayele, A., 2012. Shallow axial magma chamber at the slow-spreading Erta Ale Ridge. Nature Geoscience, 5, 284-288.

Paton, D., Smith, L., Daly, M., \& Johnston, D. 2008. Risk perception and volcanic hazard mitigation: Individual and social perspectives, Journal of Volcanology and Geothermal Research, 172, 179-188

Pyle, D. M. 2012. Small volcanic eruptions and the stratospheric sulfate aerosol burden. Environmental Research Letters, 7(3), 031001 
Ragona, M., Hannstein, F. \& Mazzocchi, M. 2011. The impact of volcanic ash crisis on the European Airline industry. In: Alemanno, A. (ed.) Governing Disasters: The Challenges of Emergency Risk regulations. Edward Elgar, Camberley

Siebert, L., Simkin, T. \& Kimberly, P. 2010. Volcanoes of the World. $3^{\text {rd }}$ edn. University of California Press, Berkeley, CA

Silva Vilanueva, P. 2011. Learning to ADAPT: Monitoring and Evaluation Approaches in Climate Change Adaptation and Disaster Risk Reduction - Challenges, Gaps and Ways Forward. Strengthening Climate Resilience Discussion Paper No. 9. Institute of Development Studies, Brighton.

Smithsonian Institution 2014. Global Volcanism Program: Volcanoes of the World 4.0. Washington DC, http://www.volcano.si.edu/

Tadele, F. \& Manyena, S.B. 2009. Building disaster resilience through capacity building in Ethiopia, Disaster Prevention and Management, 18, 317 - 326

Porkelsson, B. 2012. The 2010 Eyjafjallajokull Eruption, Iceland: Report to ICAO, Icelandic Meteorological Office, Reykjavik

United Nations Office for Disaster Risk Reduction 2005. Hyogo framework for action 20052015: building the resilience of nations and communities to disasters. World Conference on Disaster Reduction, 18-22 January, Kobe, Hyogo, Japan, http://www.unisdr.org/2005/wcdr/intergover/official-doc/L-docs/Hyogodeclarationenglish.pdf [last accessed June 2015]

United Nations Office for Disaster Risk Reduction 2015a. Sendai Framework for Disaster Risk Reduction 2015-2030. UNISDR/GE/2015 - ICLUX EN5000 1st edition. http://www.preventionweb.net/files/43291_sendaiframeworkfordrren.pdf [last accessed August 2015]

United Nations Office for Disaster Risk Reduction 2015b. Making Development Sustainable: The Future of Disaster Risk Management. Global Assessment Report on Disaster Risk Reduction. United Nations Office for Disaster Risk Reduction, Geneva, http://www.preventionweb.net/english/hyogo/gar/2015/en/gar-pdf/GAR2015_EN.pdf [last accessed August 2015]

United Nations Office for Disaster Risk Reduction 2016. Global Assessment Report on Disaster Risk Reduction 2015 - UNISDR. https://www.unisdr.org/we/inform/publications/42809 [last accessed 11 January 2016] Venton, C. 2012. The Economics of Early Response and Disaster Resilience: Lessons from Kenya and Ethiopia, 
https://www.gov.uk/government/uploads/system/uploads/attachment_data/file/67330/Ec on-Ear-Rec-Res-Full-Report_20.pdf [last accessed 27 August 2015]

Vye-Brown, C. 2014. Capacity building and preparedness for multi-hazards in Ethiopia: Workshop report. British Geological Survey Open File Report, OR/14/059

Weichselgartner, J., \& Kasperson, R. 2010. Barriers in the science-policy-practice interface: Toward a knowledge-action-system in global environmental change research. Global Environmental Change, 20, 266-277

Wolfenden, E., Ebinger, C., Yirgu, G., Renne, P. R. \& Kelley, S. P. 2005. Evolution of a volcanic rifted margin: Southern Red Sea, Ethiopia. Geological Society of America Bulletin, 117, 846864

WorldPop 2010. World population GIS dataset, http://www.worldpop.org.uk/

Wright, T.J., Ebinger, C., Biggs, J., Ayele, A., Yirgu, G., Keir, D., \& Stork, A. 2006. Magmamaintained rift segmentation at continental rupture in the 2005 Afar dyking episode, Nature, 442, 291-294

Wright, T.J., Sigmundsson, F., Pagli, C., Belachew, M., Hamling, I.J., Brandsdóttir, B., Keir, D., Pedersen, R., Ayele, A., Ebinger, C., Einarsson, P., Lewi, E. \& Calais, E. 2012. Geophysical constraints on the dynamics of spreading centres from rifting episodes on land, Nature Geoscience DOI: 10.1038/NGEO1428

Yirgu, G., Ferguson, D. J., Barnie, T. D., \& Oppenheimer, C. 2014. Recent volcanic eruptions in the Afar rift, northeastern Africa, and implications for volcanic risk management in the region. In: Ismail-Zadah, A., Fucugauchi, J.U., Kijko, A., Takeuchi, K \& Zaliapin, I. (eds) Extreme Natural Hazards, Disaster Risks and Societal Implications. Special Publications of the International Union of Geodesy and Geophysics, 1, 200-213. 


\section{Figures}

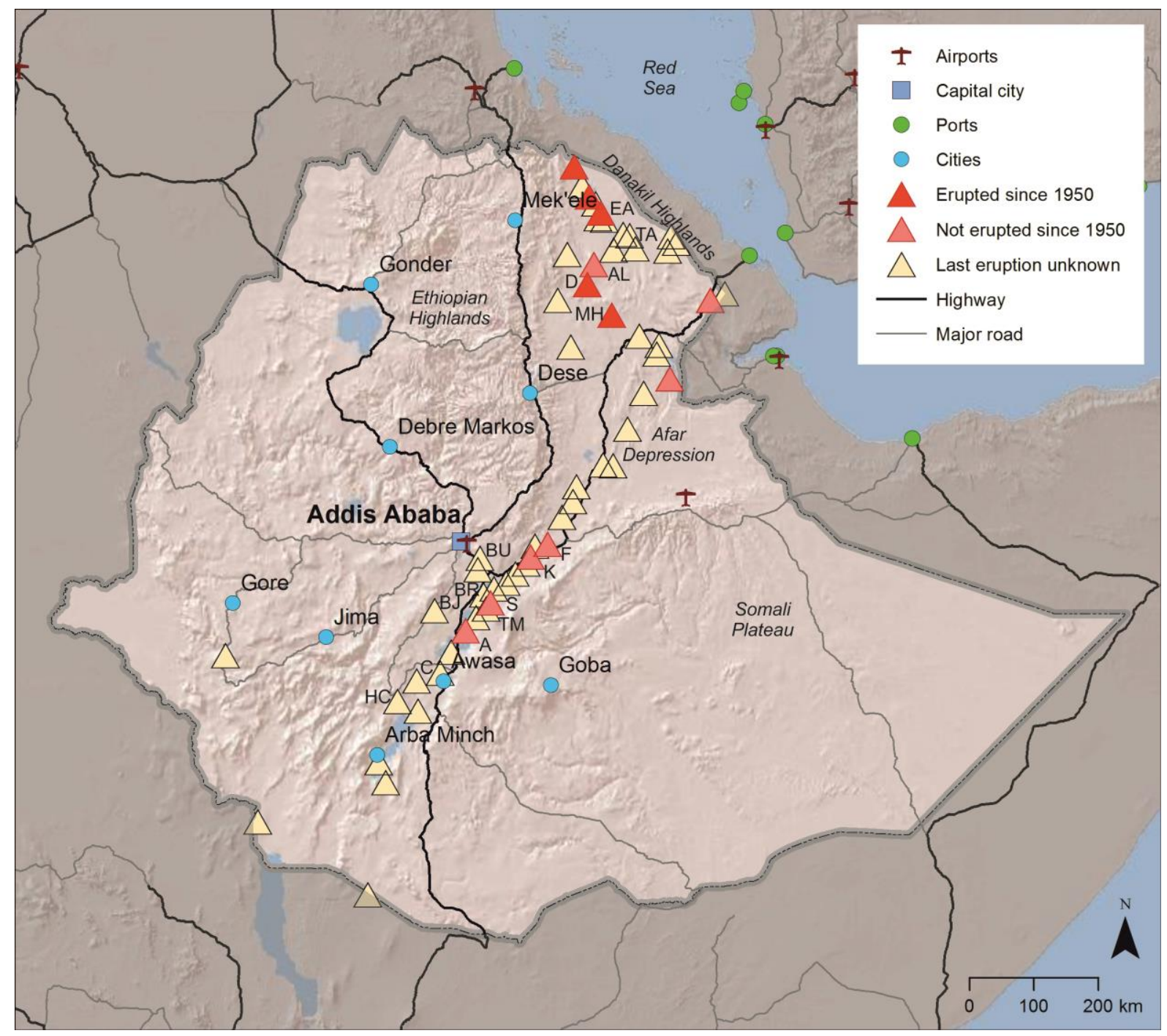

Fig. 1. Location of volcanoes in Ethiopia (pale grey): A, Alutu; AL, Alayta; BJ, Butajiri Silti Field; BR, Bilate River Field; BU, Bishoftu Volcanic Field; C, Corbetti Caldera; D, Dabbahu; EA, Erta'Ale; F, Fentale; HC, Hobicha Caldera; K, Kone; MH, Manda Hararo; S, Sodore; TA, Tat'Ale; and TM, Tullu Moje volcanoes. Data from the Global Volcanism Program of the Smithsonian Institution (Smithsonian 2014; Siebert et al., 2010; ESRI Online, 2015; NGIA 2010). 

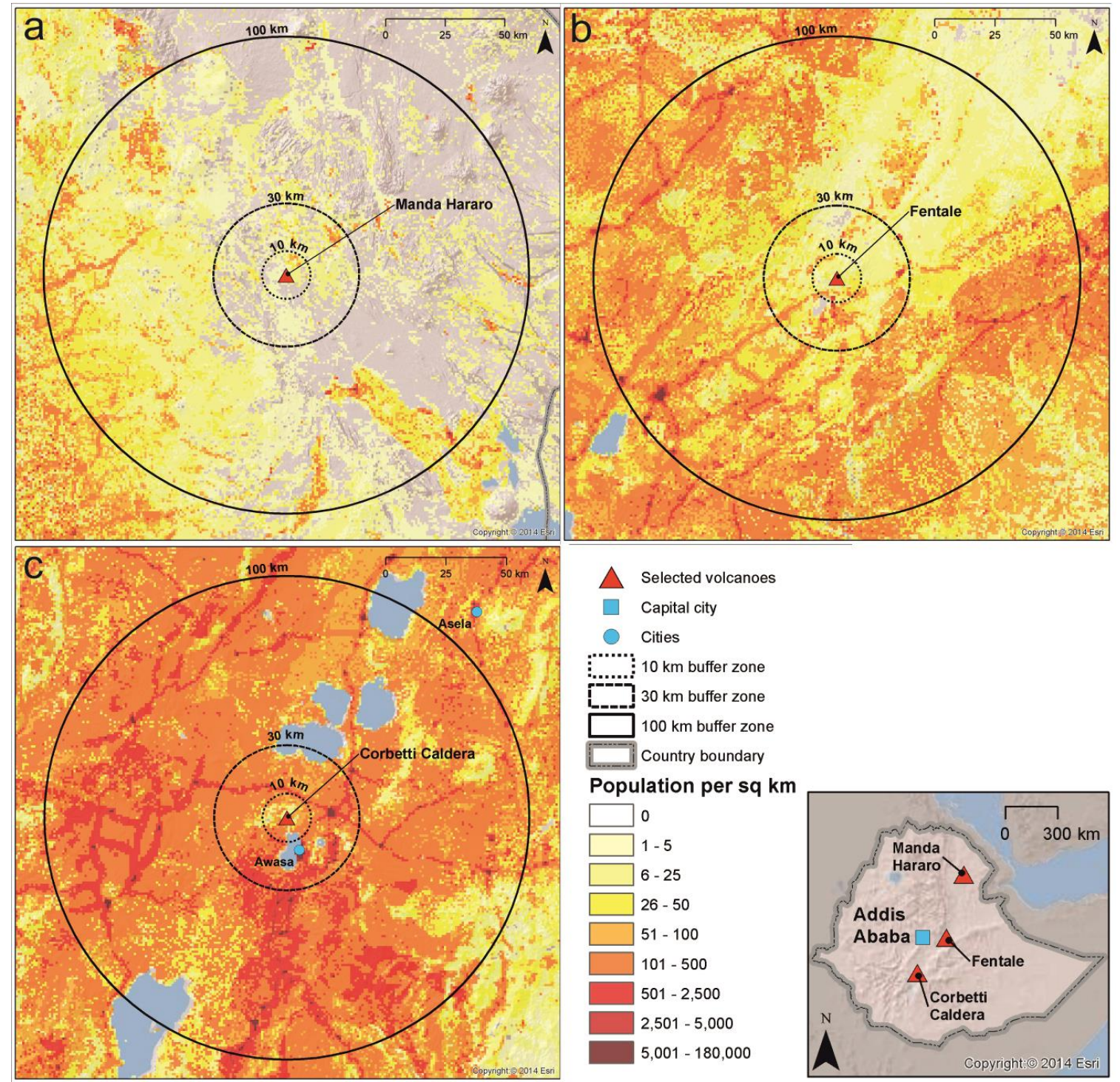

Fig. 2. Population exposure around Fentale, Corbetti and Manda Hararo volcanic centres (Map sources: ESRI Online 2014; LandScan 2014; Smithsonian 2014).

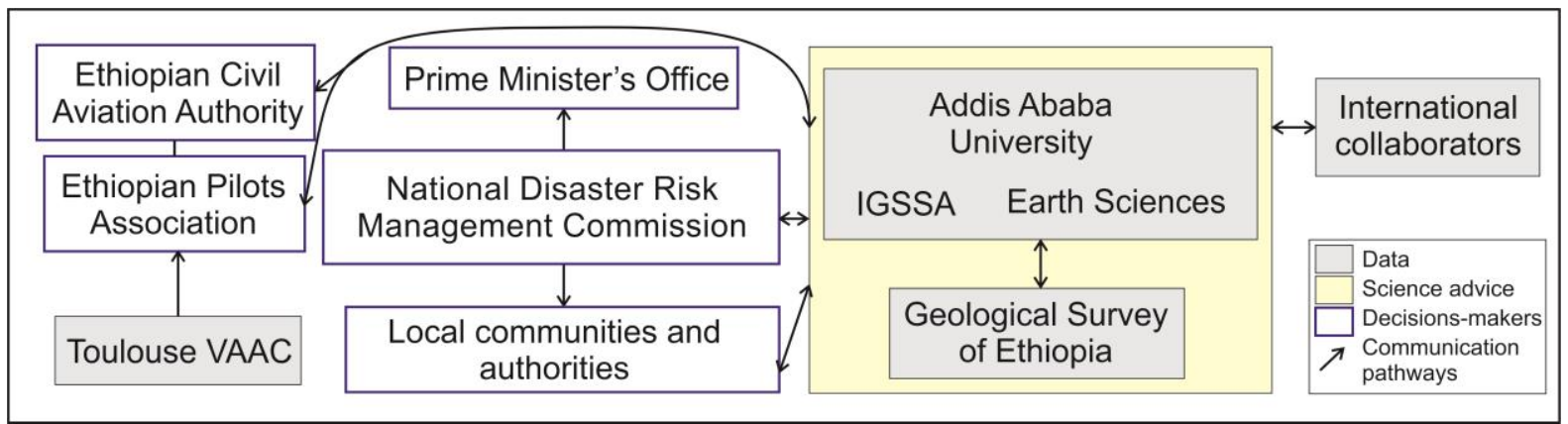

Fig. 3. Summary of the current framework for response to a volcanic crisis in Ethiopia and communication pathways. IGSSA, Institute of Geophysics, Space Science and Astronomy; VAAC, Volcanic Ash Advisory Centre. 


\begin{tabular}{|c|c|c|c|c|c|c|c|c|c|c|c|}
\hline Timeline & 2005 & 2006 & 2007 & 2008 & 2009 & 2010 & 2011 & 2012 & 2013 & 2014 & 2015 \\
\hline & $\begin{array}{llll} & A & \perp & 0 \\
\end{array}$ & $\begin{array}{lll}\mathrm{A} & 1 & 0 \\
\end{array}$ & $\begin{array}{lll}A & \perp & 0 \\
\end{array}$ & $\begin{array}{lll}\mathrm{A} & \mathrm{J} & \mathrm{O} \\
\end{array}$ & A 10 & $\begin{array}{llll}1 & A & \perp & 0 \\
\end{array}$ & $\begin{array}{lll}\mathrm{A} & \mathrm{A} & \mathrm{O} \\
\end{array}$ & $\begin{array}{lll}\mathrm{A} \perp \mathrm{O} \\
\end{array}$ & 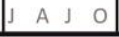 & $\begin{array}{llll} & \mathrm{A} & \lrcorner & 0 \\
\end{array}$ & $\begin{array}{llll} & A & 1 & 0 \\
\end{array}$ \\
\hline Dyke emplacement & & & & & & \multicolumn{2}{|c|}{ (13 events) } & & & & \\
\hline Volcanic eruptions & & & & & & & & & & & \\
\hline Joint fieldwork & & & & & & & & & & & \\
\hline Collaborator meetings & & & & & & & & & & & \\
\hline Workshop engagement & & & & & & & & & & & \\
\hline DRR Initiatives & $\leftarrow$ & & & & $-\mathrm{HFA}-$ & & & & 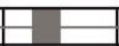 & $\rightarrow$ & SFDRR \\
\hline Projects & & UERC- & & & & AM I & & $\longrightarrow$ & $-A M \|$ & & RiftVolc - \\
\hline
\end{tabular}

Fig. 4. Timeline of events and interaction, capturing the collaborative process undertaken during the ARC project. AM I and AM II represent the French Margin Programmes (parts I and II) awarded to Raphaël Pik (CRNS, CRPG-Nancy). NSF (National Science Foundation, USA, EAR-0635789) funds awarded to a team led by Cindy Ebinger (University of Rochester, USA). ARC (Afar Rift Consortium, NE/E007414/1) funding awarded by the Natural Environment Research Council, UK, to a consortium led by Tim Wright (University of Leeds). RiftVolc (Rift Volcanism: Past, Present, Future, NE/L013460/1) funding awarded by the Natural Environment Research Council, UK, to a team led by Kathy Whaler (University of Edinburgh) and Juliet Biggs (University of Bristol). NERC urgency grants NE/D008611/1 and NE/D01039X/2 to Cindy Ebinger and Tim Wright. Dyke emplacement events from Hamling et al. (2010) and volcanic eruption dates from The Global Volcanism Program of the Smithsonian Institution (Smithsonian 2014).

\begin{tabular}{|c|c|c|c|c|c|c|}
\hline \multirow[b]{2}{*}{ Volcano } & \multicolumn{2}{|c|}{ Population within $10 \mathrm{~km}$} & \multicolumn{2}{|c|}{ Population within $30 \mathrm{~km}$} & \multicolumn{2}{|c|}{ Population within $100 \mathrm{~km}$} \\
\hline & $\begin{array}{l}\text { World Pop Africa } \\
2010\end{array}$ & Land Scan 2014 & $\begin{array}{l}\text { World Pop Africa } \\
2010\end{array}$ & Land Scan 2014 & $\begin{array}{l}\text { World Pop Africa } \\
2010\end{array}$ & Land Scan 2014 \\
\hline Manda Hararo & \begin{tabular}{|r|}
1,911 \\
\end{tabular} & 3,190 & 19,617 & 23,802 & 477,587 & $\begin{array}{r}631,766 \\
\end{array}$ \\
\hline Corbetti & 57,195 & 47,574 & $1,181,668$ & $1,550,752$ & $11,264,627$ & $12,362,318$ \\
\hline Aluto & 30,422 & 27,869 & 356,479 & 415,520 & $7,855,392$ & $8,338,404$ \\
\hline Fentale & 26,244 & 19,095 & 170,975 & 186,000 & $3,939,344$ & $4,269,628$ \\
\hline All Ethiopian Volcanoes & & $1,353,105$ & & $10,555,042$ & & $44,849,640$ \\
\hline
\end{tabular}

Table 1. Population exposure within 10,30 and $100 \mathrm{~km}$ of selected volcanoes and all volcanoes in Ethiopia: comparing population databases from World Pop (2010) and Land Scan (2014). 